\title{
FIXED POINTS AND GENERALIZED STABILITY FOR FUNCTIONAL EQUATIONS IN ABSTRACT SPACES
}

\author{
LIVIU CĂDARIU AND VIOREL RADU
}

Abstract. We use a fixed point method, initiated in [V. Radu, Fixed Point Theory 4(2003), No.1, 91-96], to prove the generalized Ulam-Hyers stability of functional equations in single variable for mappings with values in random normed spaces. This result is then used to obtain the stability for Cauchy, quadratic and monomial functional equations.

Mathematics subject classification (2000): 39B52, 39B62, 39B82, 47H09.

Keywords and phrases: Functional equation, fixed points, stability, random normed spaces.

\section{REFERENCES}

[1] T. AOKI, On the stability of the linear transformation in Banach spaces, J. Math. Soc. Japan, 2 (1950), 64-66.

[2] J. A. BAKER, The stability of certain functional equations, Proc. AMS, 112, 3 (1991), 729-732.

[3] D. G. BouRGin, Classes of transformations and bordering transformations, Bull. AMS, 57 (1951), 223-237.

[4] L. CĂDARIU, V. RADU, Fixed points and the stability of Jensen's functional equation, JIPAM, J. Inequal. Pure Appl. Math., 4, 1 (2003), Art.4 (http://jipam.vu.edu.au).

[5] L. CĂDARIU, V. RADU, Fixed points and the stability of quadratic functional equations, An. Univ. Timişoara, Ser. Mat.-Inform., 41, 1 (2003), 25-48.

[6] L. CĂDARIU, V. RADU, On the stability of the Cauchy functional equation: a fixed points approach, Iteration Theory (ECIT 02) (J. Sousa Ramos, D. Gronau, C. Mira, L. Reich, A.N. Sharkovsky - Eds.), Grazer Math. Ber., Bericht, 346 (2004), 43-52.

[7] L. CĂDARIU, V. RADU, Stability properties for monomial functional equations, An. Univ. Timişoara, Ser. Mat.-Inform., 43, 1 (2005), 23-38.

[8] L. CĂDARIU, V. RADU, Fixed points in generalized metric spaces and the stability of a cubic functional equation, Y. J. Cho, J. K. Kim \& S. M. Kang - Eds., Fixed Point Theory and Applications 7, Nova Science Publ., 2007, 53-68.

[9] L. CĂDARIU, V. RADU, Fixed point methods for the generalized stability of functional equations in a single variable, Fixed Point Theory and Applications, Vol. 2008 (2008), Article ID 749392, 15 pages.

[10] G. L. FORTI, Hyers-Ulam stability of functional equations in several variables, Aeq. Math., 50 (1995), 143-90.

[11] G. L. FORTI, Elementary remarks on Ulam-Hyers stability of linear functional equations, J. Math. Anal. Appl., 328, 1 (2007), 109-118.

[12] Z. GAJDA, On stability of additive mappings, Internat. J. Math. Math. Sci., 14 (1991), 431-434.

[13] P. GăVRUŢĂ, A generalization of the Hyers-Ulam-Rassias stability of approximately additive mappings, J. Math. Anal. Appl., 184 (1994), 431-436.

[14] A. Gilanyi, A characterization of monomial functions, Aequationes Math., 54, 3 (1997), 289-307.

[15] A. Gilany I, On the stability of monomial functional equations, Publ. Math., 56, 1-2 (2000), 201-212.

[16] O. HADŽIĆ, E. PAP, V. RADU, Generalized contraction mapping principles in probabilistic metric spaces, Acta Math. Hungar., 101 (2003), 131-148.

[17] D. H. Hyers, On the stability of the linear functional equation, Proc. Nat. Acad. Sci. U.S.A., 27 (1941), 222-224.

[18] D. H. HyeRs, Transformations with bounded m-th differences, Pacific J. Math., 11 (1961), 591-602. 
[19] D. H. Hyers, G. IsAC, TH. M. Rassias, Stability of Functional Equations in Several Variables, Basel, 1998.

[20] B. MARgolis, J. B. DiAZ, A fixed point theorem of the alternative for contractions on a generalized complete metric space, Bull. Amer. Math. Soc., 74 (1968), 305-309.

[21] D. Mineţ, V. RADU, Generalized pseudo-metrics and fixed points in probabilistic metric spaces, Carpathian Journal of Mathematics, 23, 1-2 (2007), 126-132.

[22] D. Mineţ, V. RADU, On the stability of the additive Cauchy functional equation in random normed spaces, J. Math. Anal. Appl., 343, 1 (2008), 567-572.

[23] A. K. Mirmostafaee, M. S. Moslehian, Fuzzy almost quadratic functions, Results in Math., 52 (2008), 161-177.

[24] M. MirZaVAZIRI, M. S. Moslehian, A fixed point approach to stability of a quadratic equation, Bull. Braz. Math. Soc., 37, 3 (2006), 361-376.

[25] V. RADU, The fixed point alternative and the stability of functional equations, Fixed Point Theory, 4, 1 (2003), 91-96.

[26] TH. M. Rassias, On the stability of the linear mapping in Banach spaces, Proc. Amer. Math. Soc., 72 (1978), 297-300.

[27] I. A. Rus, Principii şi Aplicaţii ale Teoriei Punctului Fix, Ed. Dacia, Cluj-Napoca, 1979.

[28] B. Schweizer, A. Sklar, Probabilistic metric spaces, North Holland, Series in Probability and Applied Mathematics 1983, Second Ed. Dover Publications 2005. 